\title{
The mutagenic effect of hydroxylamine hydrochloride on the agronomic traits of Sesame (Sesamum indicum L.)
}

\author{
Abraham Birara', Manikandan Muthuswamy² and Mebeasilassie Andargie ${ }^{2 *}$
}

\begin{abstract}
The effects of mutation induction through the use of a chemical mutagen as a method of improving few agronomic traits in sesame (Sesamum indicum L.) were investigated. Healthy and dry seeds of sesame varieties (Abasena and Kelafo 74) were treated with hydroxylamine hydrochloride (HA) at six different concentrations $(0.01,0.02,0.03,0.04,0.05 \%(w / v)$ and control) with the aim of improving the growth and yield parameters of the plant. Bioassay studies showed highly significant difference in germination percentage of the two varieties under the treatment of the mutagen compared to the control. The results obtained from the quantitative parameters also revealed highly significant increase $(P \leq 0.01)$ in the plant heights, number of seeds/pod, number of capsules/plant, internode length and capsule length with decrease in the concentration of the mutagen. In addition, days to maturity have shown a negative mean shift in all the treatments and days to flowering showed a significant positive mean shift only at $0.02 \%$ concentration of $H A$. The chemical mutagen was therefore found to improve the quantitative traits associated with growth and yield of sesame. The induced variation can be exploited in the evolution of new varieties of sesame with improved agronomic traits.
\end{abstract}

Keywords: Effectiveness; Hydroxylamine hydrochloride; Mutation; Sesame.

Received: 16 January 2014 / Accepted: 20 February 2014 / Published online: 24 February 2014

(C) Horizon e-Publishing Group

CITATION

Birara, A., Muthuswamy, M., and Andargie, M. (2014). The mutagenic effect of hydroxylamine hydrochloride on the agronomic traits of Sesame (Sesamum indicum L.). Plant Sci. Today 1(1), 33-38. http://dx.doi.org/10.14719/pst.2014.1.1.13

${ }^{1}$ Biology Department, College of Natural and Computational Sciences (CNCS), Mekelle University, Mekelle, P.O. Box 231, Ethiopia

${ }^{2}$ Biology Department, College of Natural and Computational Sciences (CNCS), Haramaya University, Dire Dawa, P.O. Box 217, Ethiopia

*Corresponding author. Email: mebhel@yahoo.com Tel.+251921655912

\section{Introduction}

Sesame (Sesamum indicum L., $2 \mathrm{n}=26$ ), which belongs to the Pedaliaceae family, is one of the most ancient oilseed crops and is cultivated in tropical and subtropical regions of Asia, Africa and South America (Brar and Ahuja, 1979; Ashri, 1998; Anilakumar et al., 2010). It is cultivated for its edible leaves used as vegetables (Mann et al., 2003) or oily seeds (Burkill, 1997). It is an important oilseed crop used to generate high quality edible oil and protein for low income peasants of major sesame growing countries including Sudan, Ethiopia, Uganda, Nigeria, Mexico, Venezuela, India, China, Pakistan, Turkey and Myanmar (Oplinger et al., 1990).

Ethiopia is known to be the origin of diversity for cultivated sesame (Bedigian, 2003). The sesame seeds harbors $50-60 \%$ oil and $25 \%$ protein with antioxidant lignans such as sesamolin, sesamin and have been used as active ingredients in antiseptics, bactericides, vermicides, disinfectants, moth repellants, anti-tubercular agents and are considerable source of calcium, tryptophan, methionine and many minerals (Bedigian et al., 1985). Attention has recently been focused on this crop in Ethiopia because of its great potential as an export commodity for its seeds. Worldwide, sesame oil is in high demand due to the importance in the confectionary industry.

Artificial induction of mutation is of scientific and commercial interest as it is one of the methods used in improving the growth and yield of economic plants. It provides raw materials for the genetic improvement of economic crops (Adamu \& Aliyu, 2007) and also used to create genetic variability in quantitative traits in various crop plants (Mahla et al., 1990; Shah et al., 1990; Mahandjiev et al., 2001). Generally mutation breeding generates a knowledge base that guides future users of mutation technology for crop improvement. The successful utilization of hydroxylamine to generate genetic variability in plant breeding has been reported in cowpea (Mensah \& Akomeah, 1992), rice (Mensah et al., 2003) soyabean 
(Mensah et al., 2013). To increase production of the crop there is a need to have a better understanding of its genetic background. However, there is no information on the locally cultivated varieties, which lack variability because of their self-pollination status. The present study was therefore undertaken to fill the gap in knowledge of the genetic background of the crop and assess the effect of the chemical on the two varieties of the plant with the aim of inducing mutation in the seeds of sesame for the improvement of its growth and yield parameters.

\section{Materials and methods}

The research was conducted in the genetics and biotechnology laboratory of the Department of Biological Sciences and at Rare agricultural research field, Haramaya University (Lat. $9^{\circ} 26^{\prime} \mathrm{N}$ and Long. 42 $3^{\prime} \mathrm{E}$ ), Dire Dawa, Ethiopia. The seeds of sesame (Sesamum indicum L.) were obtained from the Werer Agricultural Research Institute. Four hundred and forty dry and normal uniform seeds of each variety were used and these seeds were surface sterilized with $0.1 \%$ mercuric chloride for 1 minute to remove the fungal spores on the surface of the seeds. These seeds were treated at six different hydroxylamine hydrochloride (HA) concentrations $(0.01,0.02,0.03,0.04$, $0.05 \%(\mathrm{w} / \mathrm{v})$ and control) through presoaking. The treated seeds were sown in a Completely Randomized Design (CRD) with three replications in a factorial arrangement. The design of the study involved both laboratory and greenhouse experiments. Data from the laboratory based bioassay study on seed germination percentage and seedling growth and morphological traits representing the growth and yield attributes from the greenhouse study on the plant height, number of capsules/plant, capsule length, internodes length, days to $50 \%$ flowering, days to $90 \%$ maturity, number of seeds/pod and 100 seed weight were collected. All the data obtained were analyzed using Analysis of Variance (ANOVA) with least significant difference (LSD) at 1\% and $5 \%$ level of significance to separate the means. In addition, the effectiveness of mutation was determined according to the formula suggested by Konzak et al. (1965).

$$
\text { Mutagenic effectiveness }=\frac{\mathrm{MF}}{\mathrm{C} \times \mathrm{t}}
$$

where

$$
\begin{aligned}
& \text { MF: Mutation frequency (\%) } \\
& \text { C: Concentration of chemical mutagen } \\
& \text { t: Period of treatment with chemical mutagen }
\end{aligned}
$$

\section{Results}

The results obtained following the treatment of sesame seeds with different HA concentrations on seed germination, length of root, and shoot is presented in Table 1 . The highest concentration $(0.05 \%)$ showed a highly significant difference $(\mathrm{P} \leq 0.01)$ in comparison to the control and other treatments in reducing seed germination in both varieties, i.e. Abasena and Kelafo 74. The rate of germination showed a negative correlation with the mutagen concentration. HA inhibited root growth in all the concentrations, but the effect was highly significant at 0.04 and $0.05 \%$ concentrations (Table 1 ). Significant increase was also observed in shoot length at $0.01 \%$ concentration of $\mathrm{HA}$ in comparison with other treatments and the control, in addition the stimulatory effect was significant over the control plants. The other treatments displayed a negative mean shift in shoot length. Generally the inhibitory effect of HA on seed germination and seedling growth showed a similar trend on both sesame varieties.

Effects of HA on the phenological parameters of sesame varieties are shown on Table 2 . The results indicated that plant height and internodes length was significantly increased $(\mathrm{P}<0.01)$ at 0.01 and $0.02 \%$ concentration of $\mathrm{HA}$ in Abasena and Kelafo 74 varieties respectively. The maximum plant height (Table 2) at maturity of $64 \mathrm{~cm}$ was attained in $0.01 \%$ concentration while minimum plant height $(56 \mathrm{~cm})$ was observed in $0.05 \%$ HA for Abasena whereas maximum plant height of $90 \mathrm{~cm}$ was recorded for Kelafo 74 at $0.02 \%$ concentration of HA. In the present study, HA treatment in the lower concentrations has shown stimulatory effect as compared to control and the rest of the treatments. In addition, the lower doses of mutagenic treatments decreased significantly the days required for flowering and maturity. The significant changes in terms of days that are needed for flowering and maturation were observed at $0.01 \%$ concentration of HA for both varieties. Significant increase in capsule number $(\mathrm{P}<0.05)$ was observed at $0.01 \%, 0.02 \%$ and $0.03 \%$ concentration of HA treatments when compared to the control and the rest of treated plants for Abasena variety while Kelafo 74 showed a reduction in capsule number for all concentrations of HA. The HA treatment did not show any significant increase on both varieties of sesame on seed number. In general number of capsules per plant, number of seeds per pod, capsule length and hundred seed weight exhibited totally a negative mean shift in Kelafo 74 variety.

The mutagenic effectiveness was found to be the highest at lower concentration with all the mutagenic treatments in germination percentage as well as the phenological parameters of both sesame varieties (Figure 1 and 2). At $0.01 \%$ concentration of HA did not show any significant increase on both varieties of sesame, maximum effectiveness was observed in germination percentage (1335) for both Abasena and Kelafo 74 varieties. Similarly, days to maturity $(1333,1450)$ and plant height $(1067$, 1433 ) showed a highest value at $0.01 \%$ concentration of $\mathrm{HA}$ and showed a significant increase on both Abasena and Kelafo 74 sesame varieties respectively. 


\section{Discussion}

The results for the M1 generation revealed that lower doses of mutagens were effective and efficient in causing mungbean (Roychowdhury et al., 2004), in black gram (Sharma et al., 2005; in cowpea (Dhanavel et al., 2008), in little millet (Ganapathy et al., 2008; Lal et al., 2009; Thilagavathi \& Mullainathan, 2009) and in sesame

Table 1. Effects of hydroxylamine hydrochloride on seed germination and growth related parameters.

\begin{tabular}{|c|c|c|c|}
\hline Treatment & Seed germination $(\%)$ & Shoot length (cm) & Root length (cm) \\
\hline \multicolumn{4}{|c|}{ Variety Abasena } \\
\hline control & 93.87a & $6.60^{\mathrm{a}}$ & $4.53^{\mathrm{a}}$ \\
\hline $0.01 \%$ & $80.07^{c}$ & $6.89 \mathrm{~b}$ & $3.66^{b}$ \\
\hline $0.02 \%$ & $80.00^{\mathrm{d}}$ & $3.66^{c}$ & $3.30^{\mathrm{cd}}$ \\
\hline $0.03 \%$ & $63.90^{\mathrm{f}}$ & $3.24^{\mathrm{d}}$ & $3.30^{\mathrm{cd}}$ \\
\hline $0.04 \%$ & $61.30^{\mathrm{i}}$ & $3.18^{\mathrm{d}}$ & $1.92^{\mathrm{cg}}$ \\
\hline $0.05 \%$ & $52.03^{\mathrm{k}}$ & $3.00^{\mathrm{e}}$ & $1.89 \mathrm{dg}$ \\
\hline CV (\%) & 0.64 & 1.02 & 1.02 \\
\hline LSD & 0.03 & 0.06 & 0.06 \\
\hline \multicolumn{4}{|c|}{ Variety Kelafo 74} \\
\hline control & $94.90^{a}$ & $5.91^{b}$ & $3.96^{\mathrm{a}}$ \\
\hline $0.01 \%$ & $80.07^{b}$ & $6.50^{\mathrm{c}}$ & $3.84^{\mathrm{b}}$ \\
\hline $0.02 \%$ & $79.80^{c}$ & $5.61^{\mathrm{a}}$ & $3.64^{c}$ \\
\hline $0.03 \%$ & $63.00^{\mathrm{d}}$ & $4.83^{\mathrm{d}}$ & $3.60^{\mathrm{d}}$ \\
\hline $0.04 \%$ & $60.00^{\mathrm{e}}$ & $4.59 \mathrm{e}$ & $3.54 \mathrm{e}$ \\
\hline $0.05 \%$ & $52.90^{\mathrm{f}}$ & $3.63^{f}$ & $3.20^{\mathrm{f}}$ \\
\hline $\mathrm{CV}(\%)$ & 0.1 & 0.21 & 0.51 \\
\hline LSD & 0.09 & 0.01 & 0.02 \\
\hline
\end{tabular}

Table 2. Effects of hydroxylamine hydrochloride on the phenological parameters of sesame varieties.

\begin{tabular}{|c|c|c|c|c|c|c|c|c|}
\hline Treatment & $\mathbf{P H}$ & IL & DM & CL & NCPP & HSW & NSPP & DF \\
\hline \multicolumn{9}{|c|}{ Abasena } \\
\hline control & $60.00^{\mathrm{a}}$ & $11.00^{c}$ & $85.00^{\mathrm{b}}$ & $2.00^{c}$ & $15.00^{\mathrm{d}}$ & $3.00^{\mathrm{d}}$ & $50.00^{\mathrm{d}}$ & $44.00^{\mathrm{b}}$ \\
\hline $0.01 \%$ & $64.00^{\mathrm{b}}$ & $14.00^{\mathrm{a}}$ & $80.00^{c}$ & $2.00^{c}$ & $17.00^{\mathrm{b}}$ & $3.80^{c}$ & $50.00^{\mathrm{d}}$ & $40.00^{c}$ \\
\hline $0.02 \%$ & $61.00^{\mathrm{a}}$ & $12.00^{\mathrm{bc}}$ & $85.00^{\mathrm{b}}$ & $1.90^{c}$ & $16.00^{\mathrm{a}}$ & $2.50^{\mathrm{a}}$ & $48.00^{c}$ & $44.00^{\mathrm{b}}$ \\
\hline $0.03 \%$ & $60.00^{a}$ & $11.00^{c}$ & $90.00^{\mathrm{d}}$ & $1.80^{\mathrm{b}}$ & $16.00^{a}$ & $2.40^{\mathrm{b}}$ & $46.00^{c}$ & $44.00^{\mathrm{b}}$ \\
\hline $0.04 \%$ & $58.00^{c}$ & $10.00^{c}$ & $92.00^{\mathrm{cd}}$ & $1.50^{\mathrm{d}}$ & $15.00^{\mathrm{d}}$ & $2.40^{\mathrm{b}}$ & $44.00^{\mathrm{a}}$ & $45.00^{\mathrm{a}}$ \\
\hline $0.05 \%$ & $56.00^{\mathrm{bc}}$ & $9.00^{c}$ & $95.00^{\mathrm{e}}$ & $1.50^{\mathrm{d}}$ & $14.00^{\mathrm{d}}$ & $2.20 \mathrm{e}$ & $42.00 \mathrm{e}$ & $45.00^{\mathrm{a}}$ \\
\hline $\mathrm{CV}$ & 0.06 & 0.32 & 0.53 & 11.23 & 0.07 & 0.99 & 0.58 & 0.69 \\
\hline LSD & 0.08 & 0.046 & 0.60 & 0.26 & 0.014 & 0.032 & 0.035 & 0.39 \\
\hline \multicolumn{9}{|c|}{ Kelafo 74} \\
\hline control & $86.00^{\mathrm{a}}$ & $9.00^{c}$ & $85.00^{\mathrm{d}}$ & $1.80^{\mathrm{a}}$ & $12.00^{a}$ & $2.50^{\mathrm{a}}$ & $45.00^{a}$ & $40.00^{c}$ \\
\hline $0.01 \%$ & $86.00^{\mathrm{a}}$ & $9.00^{c}$ & $87.00^{\mathrm{e}}$ & $1.60^{\mathrm{b}}$ & $10.00^{\mathrm{ab}}$ & $2.40^{\mathrm{ab}}$ & $45.00^{\mathrm{a}}$ & $40.00^{c}$ \\
\hline $0.02 \%$ & $90.00^{c}$ & $9.50^{\mathrm{b}}$ & $90.00^{\mathrm{a}}$ & $1.60^{\mathrm{b}}$ & $10.00^{\mathrm{ab}}$ & $2.40^{\mathrm{ab}}$ & $45.00^{\mathrm{a}}$ & $36.00^{d}$ \\
\hline $0.03 \%$ & $85.00^{\mathrm{b}}$ & $9.00^{c}$ & $90.00^{\mathrm{a}}$ & $1.40^{\mathrm{e}}$ & $8.00^{c}$ & $2.20^{\mathrm{bc}}$ & $39.00^{\mathrm{b}}$ & $41.00^{c}$ \\
\hline $0.04 \%$ & $83.00^{\mathrm{e}}$ & $8.70^{\mathrm{a}}$ & $92.00^{\mathrm{b}}$ & $1.40^{\mathrm{e}}$ & $7.00^{\mathrm{cd}}$ & $2.20^{\mathrm{bc}}$ & $39.00^{\mathrm{b}}$ & $43.00^{\mathrm{bc}}$ \\
\hline $0.05 \%$ & $80.00^{d}$ & $8.50^{\mathrm{ab}}$ & $93.00^{\mathrm{bc}}$ & $1.20^{c}$ & $7.00^{\mathrm{cd}}$ & $2.00^{\mathrm{d}}$ & $35.00 \mathrm{e}$ & $45.00^{a}$ \\
\hline $\mathrm{CV}$ & 0.24 & 3.85 & 0.18 & 5.12 & 3.38 & 2.02 & 0.48 & 0.50 \\
\hline LSD & 0.27 & 0.45 & 0.20 & 0.10 & 0.40 & 0.06 & 0.26 & 0.27 \\
\hline
\end{tabular}

$\mathrm{PH}=$ Plant Height $(\mathrm{cm}), \mathrm{IL}=$ Internodes length $(\mathrm{cm}), \mathrm{DM}=$ Days to Maturity, CL = Capsule Length $(\mathrm{cm})$, NCPP = Number of Capsule per plants, HSW= Hundred Seed Weigh (gram), DF= Days of Flowering, NSPP = Number of seeds per pod.

polygenic variability in various quantitative characters, with a negative relationship between effectiveness and mutagen dose. These findings agreed with those in
(Ajibolu, 2005; Aliero, 2006; Begum \& Dasgupta, 2010). The lowest concentration of the chemicals $(0.01 \%)$ was the most effective in causing mutations. 
Chemical mutagenesis induced by the application of different concentrations of HA in the seeds of $S$. indicum has proved to be beneficial in the improvement of some of its selected growth and yield traits. Generally, the decrease germination in mutagenic treatments has been explained due to the delay or inhibition of physiological and biological processes necessary for seed germination including enzyme activity (Kurobane et al., 1979),

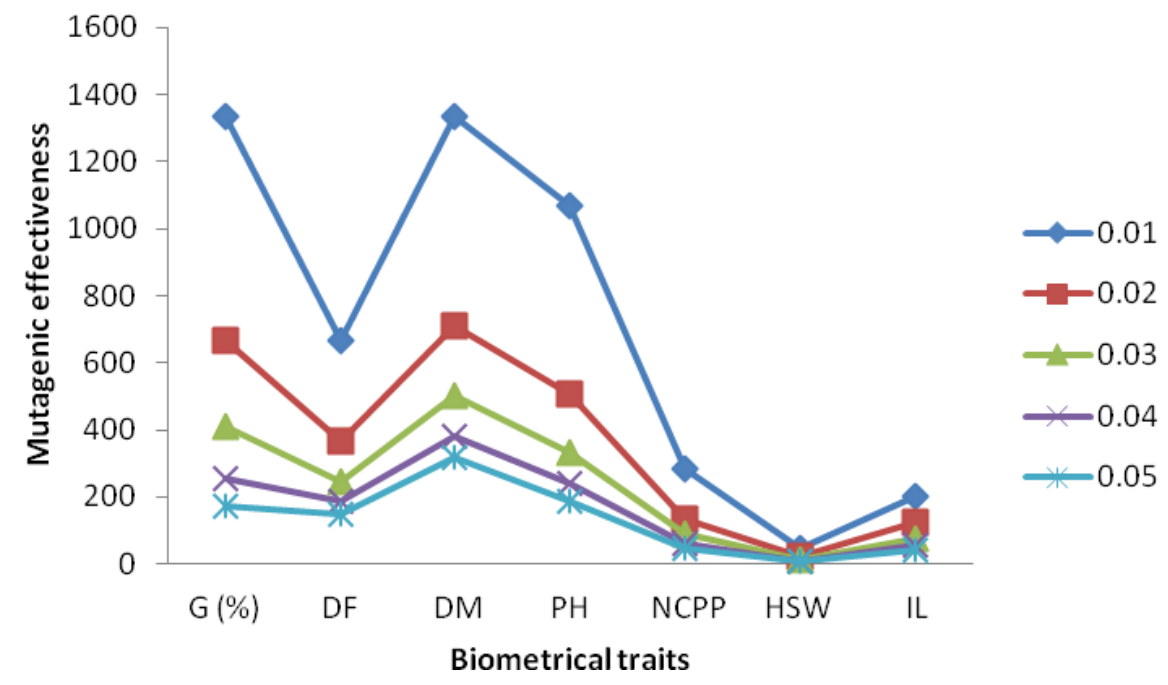

Figure 1. The mutagenic effectiveness of hydroxylamine hydrochloride on selected biometrical traits of Abasena variety at different concentration, $(\mathrm{G} \%=$ Germination percent, $\mathrm{DF}=$ days to flowering, $\mathrm{DM}=$ Days to maturity, PH = Plant height, NCPP = Number of capsules per pod, HSW = Hundred seed weight, $\mathrm{IL}=$ Intenode length).

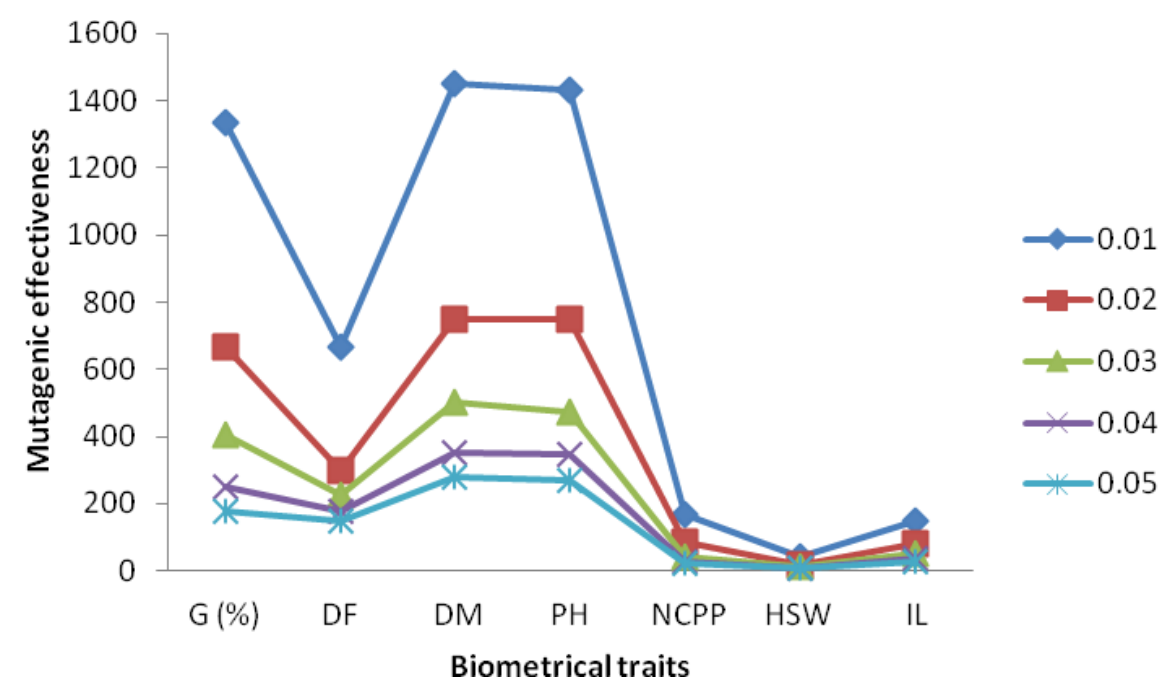

Figure 2. The mutagenic effectiveness of hydroxylamine hydrochloride on selected biometrical traits of Kelafo 74 variety at different concentration, $(\mathrm{G} \%=$ Germination percent, $\mathrm{DF}=$ days to flowering, $\mathrm{DM}=$ Days to maturity, $\mathrm{PH}=$ Plant height, $\mathrm{NCPP}=$ Number of capsules per pod, HSW = Hundred seed weight, IL = Intenode length).

in germination showed a negative correlation with the increased mutagen concentration in both varieties of sesame for the mutagen. The reduction in seed hormonal imbalance (Chrispeels \& Varner, 1967; Adamu \& Aliyu, 2007) and inhibition of mitotic activity (Ananthaswamy et al., 1971, Kulkarni, 2011). 
Root length and shoot length showed a similar pattern of growth i.e., with the increase of concentration of chemical mutagen there was adverse effect on the growth of the root length and shoot length of sesame seedlings in the laboratory conditions. The reduction in seedling survival is attributed to cytogenetic damage and physiological disturbances (Sato \& Gaul, 1967). Thus, the probable reason of this may be the hindrance caused by the HA on different metabolic pathway of the cells. Similar findings have also been reported by (Rachovska \& Dimova, 2000) in wheat, (Akhaury et al., 1996; Ilbas et al., 2005) in barley, (Adamu \& Aliyu, 2007) in tomato, (Khan et al., 2004) in mungbean, (Al-Qurainy, 2009) in Eruca sativa and (Mostafa, 2011) in sunflower.

The mean increase in plant height at maturity of the two sesame varieties induced by the chemical was due to the alteration of their genome integrated by environmental signals as reported by Uno et al. (2001); probably by increasing the rates of cellular division and expansion at their meristematic regions. Significant increase in capsule number, seed weight, capsule length and number of seeds/pod was also observed at a relatively lower concentration of the mutagen. Since capsules are seed bearing structures their increase has a positive correlation with the yield of a seed (Sureja \& Sharma, 2000). Hoballah (1999) also reported that there was an increase in the number of capsules per plant among sesame mutants.

Many workers have reported the efficiency values to be higher at lower dose of mutagens such as sodium azide (Roychowdhury et al., 2012; Khan \& Goyal, 2009), gamma rays, EMS and HZ (Siddiq \& Swaminathan, 1968; Nerker, 1976) for different agronomic and growth related parameters. Khan et al. (2004) proposed that the relative higher efficiency at lower concentration/dose of the mutagen could be ascribed to the lesser percentage of injury at such doses. General decrease in effectiveness with increasing doses of Gamma rays has been reported in foxtail millet (Gupta \& Yashvir, 1975), lentil (Sharma, 1990; Solanki \& Sharma, 1999), soybean (Menash et al., 2013). In the present study, it was also observed that effectiveness reduced with an increase in concentration in both the varieties of sesame for the different phenological parameters.

Generally, the greater sensitivity at higher mutagenic level has been attributed to various factors such as changes in the metabolic activity of the cells, inhibitory effects of mutagens and to the disturbance of balance between promoter and inhibitors of growth regulators (Krishna et al., 1984). Adegoke (1984) reported that sodium azide induces chromosomal damages leading to bridge formation during mitotic division and hence increased phenotypic aberration.

Hence it can be concluded that utilizing this chemo mutagen it is possible to foster genetic variability in a tangible way. Generally speaking the mutagenic efficiency is inversely proportional to the concentration gradient of the mutagen. Overall results indicated the possibility of obtaining sesame varieties which display more agrometrical traits variation than their parents. But the produced mutants from first generation are not adequate for studying the genetic stability, so these traits should be investigated for the desired traits in subsequent generations and in field conditions.

\section{Acknowledgments}

The authors are grateful to the Ministry of Education of Ethiopia (MOE) for the financial support to carry out this research.

\section{References}

Adamu, A.K., \& Aliyu, H. (2007). Morphological effects of sodium azide on tomato (Lycopersicon esculentum Mill). Science World Journal, 2(4), 9-12.

Adegoke, J.A. (1984). Bridge induction by sodium azide in Allium cepa. Nigeria Journal of Genetics, 5, 86-89.

Ajibolu, T.J. (2005). Effects of Chemical Mutagens on Benni Seed (Sesamum indicum L.) B.Sc. (Hons.) Project). Ambrose Alli University, Ekpoma, Nigeria, p. 49.

Akhaury, S.B., Sinha, A.N., \& Sinha, A.K. (1996). The effectiveness and efficiency of chemical mutagens on biological parameters in hullless variety of Hordeum vulgare (L.) Karan 16. Neo Botanica, 4, 1-5.

Aliero, A.A. (2006). Effect of hydroxylamine on the germination and growth of sesame (Sesamum indicum L.). Journal of Plant Sciences, 1(4), 356-361. http://dx.doi.org/10.3923/jps.2006.356.361

Al-Qurainy, F. (2009). Effects of sodium azide on growth and yield traits of Eruca sativa (L.). World Applied Science Journal, 7, 220-226.

Ananthaswamy, H.M., Vakil, V.K., \& Shrinivas, A. (1971). Biological and physiological changes in gamma irradiated wheat during germination. Radiation Botany, 11, 1-12. http://dx.doi.org/10.1016/S0033-7560(71)91257-9

Anilakumar, K.R., Pal, A., Khanum, F., \& Bawa, A.S. (2010). Nutritional, medicinal and industrial uses of sesame (Sesamum indicum L.) seeds - an overview. Agriculturae Conspectus Scientificus, 75, 159168.

Ashri, A. (1998). Sesame breeding. In J. Janick (Ed.), Plant Breeding Reviews (pp.79-228). Oxford: Oxford UK.

Bedigian, D. (2003). Evolution of sesame revisited: domestication, diversity and prospects. Genetic Resources and Crop Evolution, 50, 779-787.

Bedigian, D., Siegler, D.S., \& Harlan, J.R. (1985). Sesamine, sesamolin and the origin of sesame. Biochemical Systematics and Ecology, 13, 133-139. http://dx.doi.org/10.1016/0305-1978(85)90071-7

Begum, T., \& Dasgupta, T. (2010). A comparison on the effect of physical and chemical mutagenic treatments in sesame (Sesamum indicum). Genetics and Molecular Biology, 33(4), 761-766. http://dx.doi.org/10.1590/S1415-47572010005000090. PMid:21637588 PMCid:PMC3036137

Brar, G.S., \& Ahuja, K.L. (1979). Sesame. In C.P. Malik (Ed.), Its culture, genetics, breeding and biochemistry (pp. 245-313). Annual Review of Plant Science, Kalyani publishers, New Delhi, India.

Burkill, H.M. (1997). Pedaliaceae In The Useful Plants of West Tropical Africa (pp. 414-423). 2nd ed, Vol. 4, Royal Botanic Garden, Kew. 
Chrispeels, M.J., \& Varner, J.E. (1967). Gibberellic acid induced synthe-sis and release of $\mathrm{L}$ - amylase and ribonuclease by isolated barley aleurone layers. Plant Physiology, 42, 396-406.

Dhanavel, D., Pavadai, P., Mullainathan, L., Mohana, D., Raju, G., Girija, M., \& Thilagavathi, C. (2008). Effectiveness and efficiency of chemical mutagens in cowpea (Vigna unguiculata(L.) Walp). African Journal of Biotechnology, 7, 4116-4117. http://dx.doi.org/10.1104/pp.42.3.398

Ganapathy, S., Nirmalakumari, A., Senthil, N., Souframanien, J., \& Raveendran, T.S. (2008). Isolation of macromutations and mutagenic effectiveness and efficiency in little millet varieties. World Journal of Agricultural Science, 4, 483-486.

Gupta, P.K., \& Yashvir, A.N. (1975). Mutagenic effects of individual and combined treatments gamma rays and EMS in Okra (Abelmoscus esculentus (L.) Moench.). Journal of Cytology and Genetics, 9 \& 10, 93-97.

Hoballah, A.A. (1999). Selection and Agronomic evaluation of induced mutant lines of sesame. In Induced Mutations for Sesame Improvement (pp.71-84). IAEA-TECDOC, IAEA, Vienna.

Ilbas, A.I., Eroglu, Y., \& Eroglu, H.E. (2005). Effects of the application of different concentrations of nan3 for different times on the morphological and cytogenetic characteristics of barley (Hordeum vulgare L.) seedlings. Journal of Integrative Plant Biology, 47, 11011106. http://dx.doi.org/10.1111/j.1744-7909.2005.00137.x

Khan, S., \& Goyal, S. (2009). Improvement of mungbean varieties through induced mutations. African Journal of Plant Sciences, 3, 174-180.

Khan, S., Wani, M.R., \& Parveen, K. (2004). Induced genetic variability for quantitative traits in Vigna radiata (L.) Wilczek. Pakistan Journal of Botany, 36, 845-850.

Konzak, C.F., Nilan R.A., Wagner J., \& Foster R.J. (1965). Efficient chemical mutagenesis. Radiation Botany (suppl.) 5, 49-70.

Krishna, G., Shivashankar, G., \& Nath, J. (1984). Mutagenic response of rhodes grass (Chloris gayana Kunth.) to gamma rays. Environmental and Experimental Botany, 24(2), 197-205. http://dx.doi.org/10.1016/0098-8472(84)90022-4

Kulkarni, G.B. (2011). Effect of mutagen on Pollen fertility and seed germination in Horse gram [Macrotyloma uniflorum (Verdcourt)]. Bioscience Discovery, 2(1), 146-150.

Kurobane, I., Yamaguchi, H., Sander, C., \& Nilan, R. (1979). The effects of gamma irradiation on the production and secretion of enzymes and enzymatic activities in barley. Environmental and Experimental Botany, 19, 75-84. http://dx.doi.org/10.1016/00988472(79)90011-X

Lal, G.M., Toms, B., and Lal, S.S. (2009). Mutagenic Sensitivity in Early Generation in Blackgram. Asian Journal of Agricultural Science, 1, 911.

Mahandjiev, A., Kosturkova, G., \& Mihov, M. (2001). Enrichment of Pisum sativum gene resources through combined use of physical and chemical mutagens. Israel Journal of Plant Sciences, 49(4), 279284.

Mahla, S.V.S., Mor, B.R., \& Yadava, J.S. (1990). Effect of mutagenes on yield and its component characters in mustard. Haryana Agric University Journal of Research, 8(2), 173-173.

Mann, A., Gbate, M., \& Umar, A.N. (2003). Medicinal and economic Plants of Nupe land. Jube- evans books and publications, Bida, Niger state.

Mensah, J.K., \& Akomeah, P.A. (1992). Mutagenic effects of hydroxylamine and streptomycin on the growth and seed yield of cowpea (Vigna unguiculata (L.) Walp). Legume Research, 15(1), 3944.
Mensah, J.K, Eruotor, P.G., Iyeke, J.E, \& Ekpekurede, E.O. (2003). Mutagenic effect of hydroxylamine, streptomycin and urea on the agronomic characters of rice (Oryza sativa L. CV ITA 150). Indian Journal of Agricultural Research Karnal-India, 37(2), $88-93$.

Mensah, J.K., Okooboh, G.O, \& Osagie, I.P. (2013). Mutagenic effects of hydroxylamine and hydroquinone on some agronomic and yield characters of soyabean (Glycine max (L) Mer),InternationalJournalof Modem Botany, 3(2), 20-24.

Mostafa, G.G. (2011). Effect of sodium azide on the growth and variability induction in Helianthus annuus L. International Journal of Plant Breeding and Genetics, 5, 76-85. http://dx.doi.org/10.3923/ijpbg.2011.76.85

Nerker, Y.S. (1976). Mutation studies in Lathyrus sativus. Indian Journal of Genetics, 36, 323-329.

Oplinger, E.S., Putnam, D.H., Kaminski, A.R., Hanson, C.V., Oelke, E.A., Schulte, E.E., \& Doll, J.D. (1990). Sesame. University of Minnesota, USA.

Rachovska, G., \& Dimova, D. (2000). Effect of sodium azide and gamma rays on $\mathrm{M}_{1}$ quantitative characteristics of the productivity and their connection with $\mathrm{M}_{2}$ mutation changes in winter common wheat. Rasteniev dni- Nauki, 37, 413-419.

Roychowdhury, B., Dasgupta, T., Das, A., \& Das, P.K. (2004). Gamma ray and ethyl methane sulphonate induced chlorophyll mutations in mungbean [Vigna radiata (L.) Wilczek]. Bangladesh Journal of Genetics and Biotechnology, 5, 23-26.

Roychowdhury, R., Datta, S., Gupta, P., \& Tah, J. (2012). Analysis of genetic parameters on mutant populations of Mungbean (Vigna radiata L.) after ethyl methane sulphonate treatment. Notulae Scientia Biologicae, 4(1), 137-143.

Sato, M., \& Gaul, H. (1967). Effect of ethyle methane sulphonate on the fertility of barley. Radiation Botany, 7, 7-15. http://dx.doi.org/10.1016/0033-7560(67)90028-2

Shah, S.A., Ali, I., \& Rahman, K. (1990). Induction and selection of superior genetic variables of oilseed Rape (Brassica napus L.). The Nucleus, 27(1-4), 37-40.

Sharma, S.K. (1990). Mutagenic effectiveness and efficiency of EMS, DES and Gamma rays in lentil. Cytologia, 55, 243-247. http://dx.doi.org/10.1508/cytologia.55.243

Sharma, S.K., Ritu, S., \& Pandey, D.P. (2005). Studies on mutagen sensitivity, effectiveness and efficiency in urdbean [Vigna mungo (L.) Hepper]. Indian Journal of Genetics, 65, 20-22.

Siddiq, E.A., \& Swaminathan, M.S. (1968). Enhanced mutation induction and recovery caused by NG in Oryza sativa L. Indian Journal of Genetics, 28, 297-300.

Solanki, I.S., \& Sharma, B. (1999). Induction and isolation of morphological mutations in different mutagenic damage groups in lentil. Indian Journal of Genetics, 59, 479-485.

Sureja, A.K., \& Sharma, R.R. (2000). Genetic variability and heritability studies in garden pea (Pisum sativum L.). Indian Journal of Horticulture, 57, $243-47$.

Thilagavathi, C., \& Mullainathan, L. (2009). Isolation of macro mutants and mutagenic effectiveness, efficiency in black gram [Vigna mungo (L) Hepper]. Global Journal of Molecular Sciences, 4, 76-79.

Uno, G., Storey, R., \& Moore, R. (2001). Principles of Botany. Mc Graw Hill New York.

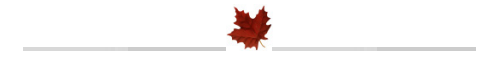

